\title{
The Genesis, Divisions, Movement and Transformation of Okkaligar Community
}

\author{
V.T. Sundaramurthy \\ The Crops Foundation Trust, Veerakeralam, Coimbatore 641 007, Tamilnadu, India \\ Telephone: +91-422-2473853, E-mail: vtsmurthycbe@yahoo.co.in
}

KEYWORDS India, Movement, Transformation, Diversification

\begin{abstract}
Okkaligar is one of the major communities native to India belongs to Dravidian family and originated from the Himalayan range. They lived in the regions of Punjab, Rajasthan, Delhi, Gujarat, Bengal and the regions lying between Ganga and Yamuna rivers and moved down to South through Mazhava, Birar, and Bhamini States due to harassment of the rulers of these regions. The population of Okkaligar is dominant in Karnataka followed in Tamilnadu and Andhra Pradesh States of India. The community under went several transformations to have ten sub -divisions and several sects. Though their main occupation is farming they posses native skill and expertise in a number of fields that helped to develop the forestry, education, linguistics, arts, culture, health and medicine, sciences including the modern technologies, industries, trades, commerce, charity, social, justice, law and order, state administration, politics and cinematography.
\end{abstract}

\section{INTRODUCTION}

India occupies only $2.4 \%$ of the world's land area and supports over $15 \%$ of the world's population. She is known for her unique diversity of climate, soils, vegetations, animals, people, languages, faiths, cultures, and castes and was originally inhabited by the diverse groups comprising the Dravidian, Mongoloid, Negrito, and Austroloid races in ancient time. According to the British Historian Abert India was ruled by 56 kings and 26 of them were Kannadigars of Dravidian origin who were native to India and belonged to Tamulic family. The term Tamulic was later changed as Dravidian by Bishop Caldwell. (Thurston and Rangachari, 1909). The term Okkaliga means agriculture derived from their traditional profession of cultivation of crops. It is also known under different names viz, Kammakula Okkaliga, Карри and Ки.Карри in some settlements in South India where they had guarded the Lingams ${ }^{(1)}$ from the bigots during the early period of Kaliyugam (Subbaiah, 1911). The origin of Okkaligars, their diversity and contributions to society are not fully understood and the fractured facts that are available at different regions are presented in this paper.

\section{ORIGIN AND MOVEMENT OF OKKALIGAS}

The history of Okkaligars date back to the dawn of the era Duvabarayugam (4000 - 3102 $\mathrm{BC}$ ) and came into existence from the sticking milk that was poured over the Lingams of God Shiva by the Kamadhenu ${ }^{(2)}$. They were very traditional, modest, non- aggressive and peaceloving people and led a disciplined life in the forest area of the Himalayan range by adhering strictly to the moral codes for living. They were secular and did not have any stratification in their commune during pre- Vedic period but worshiped the God Shiva in the form of Lingams. According to various inscriptions that were found on the copper plates and palm leaves in Archives in South India they were originally 48 in numbers (Table 1), named after their characters and physiques and considered as fore -fathers of the modern Okkaligars. Among them Avunavaru, Badavanaru, Basalenavaru, Emmenavaru, Dasalenavaru, Danyathavaru, Hundenavaru, Jaladenavaru, and Janakallinavaru got married to beautiful girls of Shri Krishna Kula Nagakanni set of Yadhava community and rest of them were married to the offsprings of these couples by following the system of the brotherhood and living in the Himalayan regions and moved around Delhi during the pre-Vedic periods (Subbaiah, 1911).

The Aryans ${ }^{(3)}$ who invaded had disregarded the local cultures and occupied greater part of North India by pushing others to southwards or towards the jungles and mountains in North India (Daniel, 2004). The Manu dharma Sasthra rules for living was devised to degrade the indigenous Dravidians during the reign of Huns who tyrannically suppressed and oppressed them in 
Table 1: Names of forty-eight Okkaligas that latter became the names of the Kulams and their attributes (after Subbaiah, 1911).

\begin{tabular}{|c|c|c|}
\hline 1.Alenavaru & 17.Gudioru & 33.Kuloru \\
\hline (Alcohol free) & (Guard, guest) & (Traditional people) \\
\hline 2.Alpenavaru & 18.Hundenavaru & 34.Mansanvaru \\
\hline (Used to be Aloof) & (Humorous one) & (Recite Hymen) \\
\hline 3.Alunavaru & 19.Huliyaru & 35.Mayoru \\
\hline (Philanthropist) & (Humane people) & (Confused one) \\
\hline 4.Andenavaru & 20.Janakallinavru & 36.Ollakkaloru \\
\hline (Good Anchors) & (Caretaker) & (Celebrity) \\
\hline 5.Arasanavaru & 21.Jannakkoru & 37. Onamanavaru \\
\hline (Guru, Judge) & (Warden) & (Powerful one) \\
\hline 6. Avinavaru & 22.Jaladenavaru & 38. Rageoru \\
\hline (Traditional) & (Jailor) & (Crazy people) \\
\hline 7.Badavanavaru & 23.Jeriyoru & 39. Ravuththnaoru \\
\hline (Singer) & (Entertainers) & (Chatter) \\
\hline 8.Basalenavru & 24.Jeerikkoru & 40.Saradenavaru \\
\hline (Traders) & (Jealous people) & (Intelligent People) \\
\hline 9.Bellenavaru & 25.Kallaioru & 41.Sarangathoru \\
\hline (Aggressive one) & (Karma) & (Wisdom People) \\
\hline 10.Danyathavaru & 26.Kamblioru & 42.Settenavaru \\
\hline (Elegant people) & (Juvenile in nature) & (Decision makers) \\
\hline 11.Dasalenavaru & 27.Kankalanavaru & 43. Soolenavaru \\
\hline (One who stitches) & (Zealous) & (Vocalists) \\
\hline 12.Ellaioru & 28. Karikkenavaru & 44.Thabbakkioru \\
\hline (Elite people) & (Youthful) & (Textile makers) \\
\hline 13.Emmenavaru & 29.Kakkiyavaru & 45. Thomkuthioru \\
\hline (Diplomat) & (Enthusiastic one) & (Meticulous one) \\
\hline 14.Eradukkarioru & 30.Kattaratavaru & 46.U1lenavaru \\
\hline (Absent minded) & (Ardent people) & (Autocrat) \\
\hline 15.Ethirukaraioru & 31.Koopaenavaru & 47.Uthathoru \\
\hline (Moral people) & (With eye makeup) & (Toolmakers) \\
\hline 16.Goniyoru & 32.Kokkenavaru & 48. Uthenavaru \\
\hline (Rigid people) & (Knowledgeable) & (Commandeer) \\
\hline
\end{tabular}

Northern India (Deivanayagam and Devakala, 1997) and forced them to migrate to different regions. The Hindu King Chandragupta-II who ruled North India during the post -Vedic period by waging the wars also pushed the Okkaligars further from Delhi to other regions. They found their way to Punjab, Rajasthan, Gujarat, and regions lying between Ganga and Yamuna rivers (Palaniswamy, 1988), suggesting that the Hindus did have conflicts, unhealthy competition and inbuilt rivalry in those days as in the modern era, which alienated the people and exposed them to invasions by foreigners.

The Nawabs who ruled India were also in opposition to Okkaligars as they resisted to have their daughters married to them. The atrocities committed by the rulers on them in the North, and subsequently in the Central India made them to move to the Thungabadra River area in the South through Mazhava, Birar of Central India and Bhamini State lying on the South of Krishna River for safeguarding the interests of their women flock. The existence of 15 Dravidian languages out of 430 living languages of India in several regions of Himachal Pradesh, Jammu and Kashmir, Delhi, Punjab, Haryana, Madhya Pradesh, Maharastra, Gujarat, Orissa and West Bengal (Gordon Raymond, 2005) is possible evidence to show that the Okkaligars might have spread to these regions while fleeing from the North to the South during different periods of history (Figure 1). The River Thungabadra was in spate at the time of their arrival and found difficult to cross. Their chief Janakkallar made the prayers and offered sacrifice to God, which enabled them to cross the river on 18th of Adi Month i.e. $3^{\text {rd }}$ or $4^{\text {th }}$ of August (Subbaiah, 1911). According to the other version available with the Archeological Department at Coimbatore one of the Chieftains, Jallathipparaya (Jallam = water, Thipparaya $=$ come back) was responsible for getting them to other side of Thungabadra River through his prayers and sacrifice (Palaniswamy, 1988). The event of crossing the River was being remembered every year by most of the South Indian communities irrespective of castes on 18th of Adi Month by celebrating it as 'Adi Perukku' (4) festival. It is performed not only for the 
prosperity of the family and society but also to remember the sacrifice made by their forefathers on this day while crossing the River. The population mourns and worships their forefathers on this day by conducting rituals and presenting a piece of new black cloth or floating the banana leaf that carries the lighted small oil mud lamps, flowers and eatables on either the running rivers or any other water sources. The people in South consider this month as an inauspicious one and do not either initiate or launch any new ventures and other auspicious family functions including marriages. The newly married couples remain separated during the Month of Adi or Ashada in South Indian States perhaps to remember the ordeals that their fore fathers under went while migrating from their previous habitats. According to the Hyderabad and Arekaree Allakur Gazetteers the population of Okkaligars was found to exist at Godhavari region in A.D.8 and 10th centuries (Palaniswamy, 1988). They moved beyond Thungabadra River down to South and settled in a group at a place Nandana Hosur named after the Nandhi ${ }^{(5)}$. The disturbances that possibly took place at Nandana Hosur in latter periods might have forced them to migrate to other places. Many of them were moved towards the Martha region presently Maharastra in 1224 and Tamilnadu in 1565 after the Thalaikottai War. According to the Ethnographic Survey of Karnataka the successive influx of population that took place from the Western Martha region into Chitradurg and Tumkur areas of Karnataka might have set in the ecological succession that displaced their community down to Tamilnadu (Anonymous, 1899, $1914 \mathrm{a}, \mathrm{b}$ ). The harassment of the rulers and social upheavals or onset of drought followed by famine at their previous habitats might also be probable causes for their migration to Tamilnadu from Karnataka.

They settled down at various parts in Tamilnadu mostly along the mountain range of the Western Ghats as the natural barriers around these habitats had provided them confidence for their peaceful living. The community had grown with a flourishing civilization relaying heavily on the fertile soils, abundance of wild life, fruits and other agricultural commodities at these habitats in Tamilnadu. There is another story that a Chieftain of Okkaligar community from Bellary area of Karnataka invaded Madurai in Tamilnadu and ruled for a brief period. It is likely that the people who came along with him had settled down in and around the western region of Madurai on the mountain range of the Western Ghats. The people who migrated towards East founded their settlements in the present Orissa and Bengal regions, formed their kingdom and named as Gowda Desam (Palaniswamy, 1988). Wherever they went they built the 'Ammasimane' at their settlements and accommodated their Kula Devathaigals (Family Deities). There are more than 190 such family temples spread over 150 different villages covering 50 taluks in 13 Districts of Andhrapradesh, Karnataka and Tamilnadu (Veerakyathaiah, 2005). The people of the community who settled down in different places of South and other States worshiped the Kula Devathaigals at Ammasimane by paying frequent visits on pilgrimages. They also organized an important festival called 'Jathrai' once in 12 years at their different settlements where the kula deity had been sanctified and offered their prayers for the welfare of people as preached by their chief at the time of crossing the River. This festival is being followed even now and has become an annual feature in some of the settlements in the modern days.

\section{TRANSFORMATION AND DIVERSITY OF THE COMMUNITY}

The Vedic Aryans by manipulating the Rigveda forced India to embrace the new culture of divisions of labour based on 'Varnams' and many other practices and beliefs around $1500 \mathrm{BC}$ for their material comforts, personal gains and general welfare with the view to integrate the multiracial society into one complex system (Jayaraman, 2001). The divisions included were Brahman, Kshatria, Vaisia and Sudra and each of them were assigned with specific occupational duties. This system had helped them to master various spheres of human management from generation to generation with in the divisions, as there was no well-organized educational system to offer this knowledge to others as in the modern days. The Sudra was the most affected group under the varnams system in the society. The social system of the division of labour is considered as forerunner for development of the 'caste system' based on the Brahminical ideology in India and it was not a creation of divine power as claimed by some sectors in the society. However the molecular biologists of the modern age attribute the genetic variations that they 
found among the upper and lower castes to the origin of the cast system in India in the modern era. (Basu et al., 2001). Even though the caste system claimed to have given stability to society (Hebbar, 2001) it is considered as an instrument that is responsible for the social disharmony, rivalry among different castes and exploitation with in and outside the castes. Several Tamil inscriptions of the medieval era have revealed the existence of a social formation that had emerged as a challenge to the hierarchical caste system based on Brahminical ideology (Karashima, 2006).

The Okkaligars was neither a caste nor a cult in previous periods of history also succumbed to the influence of this system and became one of the dominant 'castes' in the Indian society which undergone several transformations and fractured into different sub divisions such as Kunchidiga okkaligar, Gudiokkaligar, Gangadiga okkaligar, Keeraikara okkaligar, and Kappu okkaligar. The other endogamous sub divisions of negligible importance are Kamati, Gauri, Bai and Sanu (Thurston and Rangachari, 1909). Kunchidigar literally means traditional and they were known for conservatisms and ardent followers of traditions and lived in camps by earning their lively hood through laboring in the farms. The Gudiokkaligar literally means guard or guest that perhaps related either to the duty of guarding the community or they were known for entertaining the guests and this division is an off shoot of one of the kulams viz Gudioru [Gudi =guests, oru =company, also used to call a person in respectable way in their Kannada language]. The Gudioru carries the same meaning as that of Gudiokkaligar suggesting that they suffixed the community name 'okkaligar' after the kulam for others to recognize them easily as Okkaligar in the new habitats. However according to another version they were concerned with the activities of temples. The Gangadiga okkaligars were healthy and honest business people. The same postulation holds good for the Kappuokkaligars also and they protected the Lingams from bigots at their settlements. The Kerraikarar okkaligar were very honest and keep up their words as understood from the meaning of the name of the sect and their main occupation was cultivating 'kirai' (Amranthus leaves) and other vegetables. They were also called as Kempatti okkaligars as they migrated from Kempampatti region of Mysore and penetrated deep into South of
Tamilnadu via Coimbatore and Madurai (Thurston and Rangachari, 1909). Since they originated from the Lingams of Lord Shiva and married to the girls of the family of Lord Krishna during the pre Vedic period they followed both the Saivite and Vaishnavite traditions of Hinduism as in the modern days.

This community was further fractured into more than thirty castes in South India. They are Allikkar, Alubalija Naidu, Arumudi, Basunadi, Belakavadi, Devaru, Dhandi-vandake, Eazhibkka, Ellamakappu, Gangala, Gowda, Kamma, Konganiga, Kumbi, Malava, Musuku, Moasureddy, Murlay, Namathari, Nadavaru, Nunubha, Nunubhakappu, Okkulu makkalu, Osadevaru, Palayakottai Pattakkarars, Pandi, Pandaru bellakudi, Pammareddy, Pattikasalina, Reddy, Sathsappa, Summareddy, Uppinagonika and Varajha. The genetic, ethnographic, and historical studies have shown that the castes of the Hindu have been highly endogamous for several thousand years (Wooding et al., 2004). The ways of living, mannerisms, customs, ceremonies and rituals that are being followed in the traditional functions such as attainment of puberty by girls, weddings and the burial of dead bodies by the people of these castes are same as that of the customs that are being followed by Okkaligars with a little deviation which supports the current view that these castes are endogamous entities of Okkaligar community of the Hindu. According to Madurai Gazetteers the Kappiliyan are respectable and honest agriculturists, who migrated from Andhra Pradesh with the help of Palayakottai Pattakkarars as Thottiyan and Muslims ravished their women folk and latter they became Gownden of Velhala Gounder community of Tamilnadu are also Okkaligas (Thurston and Rangachari, 1909). The agriculturists of the Thooran Kootam of the Konghu Velhala Gounder community are also migrated from Halebedu, the southern region of Mysore in Karnataka State due to some reasons or other (Natarasan, 1999). They used to have names such as Gowda, Gowder, Gounder, Reddy, Rao, Naidu and Naicker as the title after their name in the States of Andhra Pradesh, Karnataka and Tamilnadu and these names are being used in the modern time to identify the group to which a person belongs.

The facts that were brought to light in the beginning of nineteenth century by Thurston and Rangachari (1909) on the stature, head size, 
head and nasal indices of thirty different castes also objectively confirm that they did not differ in their basic anatomy and they were one and the same (Table 2). The statistical scrutiny of the data presented by Thurston and Rangachari also reveal that the variations found among the different castes are not significant except the Toda, suggesting that they were one and the same of Dravidian origin. The recent discovery of a Neolithic stone Celt with the Indus script of Dravidian language at Mailaduthurai in Tamilnadu provides the evidence for existence of people of Dravidian origin in South India between 2000 BC and $1500 \mathrm{BC}$ (Anonymous, 2006).

The results of recent studies on mtDNA, of Y-chromosome and autosomal genes indicate that the Indian tribal and caste populations derive largely from the same genetic heritage of Pleistocene (Kivsild et al., 2003b; Cordaux, 2004). The occurrence of similar DNA in the Indian population right across the country indicates that the population is originated from a single biological entity (Bamshad et al., 1998). However the populations of upper-castes of North India as against South India are genetically closer to the populations of Central Asia (Basu et al., 2003). Although the South Indian population remained distinct and endogamous for several thousand years by following a set of rigid customs for living there was 1-2\% migration per generation between different caste groups with differential rates of gene flow mostly through maternal origin (Wooding et al., 2004).

\section{DISTRIBUTION OF OKKALIGARS}

The populations of Okkaligar of different subdivisions had settled down in the districts of Darwar, Davengere, Chitradurga, Bellary, Raichur, Tumkur, Kolar, Bangalore, Shimoga, Hassan, Mandya and Mysore of Karnataka State; Anantapur district of Andhra Pradesh and Palaghat of Kerala State in South India. They had also settled down in more than 200 villages in the districts of Dharmapuri, Salem, Nilagiris, Coimbatore, Erode, Karur, Trichy, Dindigul, Madurai, Theni, Tirunelvelli and Kancheevaram in Tamilnadu State of Southern India. Among the different sub- divisions of Okkaligars Kunchidigar belonging to more than 35 Kulams out of 101 known (Veerakyathaiah, 2005) are densely populated in Dharmapuri, Dindigul, Theni, Madurai and parts of Coimbatore regions than in other districts of Tamilnadu State while the population of other sub-divisions are coexisting with them. Similarly a dense population of Okkaligar is found in the districts of Chitradurga, Tumkur, Bangalore and Mysore in the state of Karnataka. They are also found in various cosmopolitan cities of Andhrapradesh, Karnataka and Tamilnadu States in Southern India (Fig.1).

The people who had settled down at various habitats did not mingle with each others in the earlier days perhaps due to self-esteem of remaining independent, or status of families and restricted mobility due to want of easy transports. Efforts had been made to amalgamate all the sub groups into one but it was not materialized due to the fear that the majority might make others insignificant in the society. The negative approach of certain groups to come together had greatly affected their generations and isolated from each other's. The offsprings who were born to one of the parents from other settlements or States are better than the one married within the settlement in terms of intelligence and personality. The frequent failure of crops due to erratic monsoon, awareness on the importance of education, massive development of educational systems and availability of the cheap public transport facilities in and around their settlements facilitated them to acquire education with ease in different habitats in the modern era which improved their intellectual capability. The various social measures of the Governments including declaration of several communities including okkaligars as a Backward Class also enabled them to empower and improve the living standard of not only Okkaligars but also other weaker sections of Dravidian origin, which suffered heavily under the "Varnashrama Dharma" from its inception to modern era.

The growth of intellectual capability, marked economic changes that are in progress in the society around them and broad outlook of the current generation are changing the attitudes of conservatives who are mentally prepared to mingle with each others in recent years for the prosperity of their offspring and communities. The unification of okkaligars under changing system with improvement of their economic status is possible by shedding the names of sub-divisions, retaining their kulams and developing the biological relationship between each group and also other endogamous sects. The unification of different sub-divisions and castes is socially 
Table 2: The similarity in the physical traits of different South Indian castes in nineteenth century (after Thurston and Rangachari, 1909).

\begin{tabular}{|c|c|c|c|c|c|}
\hline \multirow[t]{2}{*}{ Names of the castes } & \multirow[t]{2}{*}{ Stature $(\mathrm{cm})$} & \multicolumn{2}{|c|}{ Head Size $(\mathrm{cm})$} & \multirow{2}{*}{$\begin{array}{l}\text { Head } \\
\text { Index }\end{array}$} & \multirow{2}{*}{$\begin{array}{l}\text { Nasal } \\
\text { Index }\end{array}$} \\
\hline & & Length & Breadth & & \\
\hline Smarta & 164.2 & 18.8 & 14.0 & 74.5 & 71.5 \\
\hline Madhava & 163.3 & 18.4 & 14.3 & 88.5 & 72.0 \\
\hline Hebbar & 163.2 & 18.4 & 14.7 & 80.1 & 71.5 \\
\hline Pattar & 157.2 & 18.7 & 14.4 & 77.6 & 92.9 \\
\hline Mean & 162.1 & 18.6 & 14.4 & 80.0 & 77.0 \\
\hline $\mathrm{CD}$ & 5.91 & 0.41 & 0.57 & 11.76 & 20.81 \\
\hline 95\% Upper confidence Limit & 157.27 & 18.24 & 13.89 & 70.62 & 60.08 \\
\hline 95\% Lower confidence Limit & 166.87 & 18.90 & 14.81 & 87.73 & 93.87 \\
\hline \multicolumn{6}{|l|}{ II. Jungle Tribes } \\
\hline \multirow[t]{2}{*}{ Names of the castes } & \multirow[t]{2}{*}{ Stature $(\mathrm{cm})$} & \multicolumn{2}{|c|}{ Head Size $(\mathrm{cm})$} & \multirow{2}{*}{$\begin{array}{l}\text { Head } \\
\text { Index }\end{array}$} & \multirow{2}{*}{$\begin{array}{l}\text { Nasal } \\
\text { Index }\end{array}$} \\
\hline & & Length & Breadth & & \\
\hline Toda & 169.8 & 19.4 & 14.2 & 73.3 & 74.9 \\
\hline Irula & 159.8 & 18.2 & 13.7 & 76.4 & 86.1 \\
\hline Sholaga & 159.3 & 18.2 & 13.6 & 73.4 & 84.9 \\
\hline Chenchu & 158.0 & 18.2 & 13.5 & 74.3 & 81.9 \\
\hline Kurumba & 158.0 & 17.9 & 13.7 & 76.4 & 86.1 \\
\hline Kadir & 157.7 & 18.4 & 13.4 & 72.9 & 89.8 \\
\hline Malavedan & 154.2 & 18.5 & 13.6 & 73.4 & 84.9 \\
\hline Paliyan & 150.5 & 17.8 & 13.5 & 75.7 & 95.5 \\
\hline Mean & 158.4 & 18.3 & 13.65 & 74.6 & 85.4 \\
\hline $\mathrm{CD}$ & 10.82 & 0.98 & 0.47 & 11.58 & 5.91 \\
\hline 95\% Upper confidence Limit & 153.79 & 17.88 & 13.44 & 73.49 & 80.44 \\
\hline 95\% Lower confidence Limit & 163.03 & 18.72 & 13.85 & 75.69 & 90.33 \\
\hline \multicolumn{6}{|l|}{ III. Other Lower Castes } \\
\hline \multirow[t]{2}{*}{ Names of the castes } & \multirow[t]{2}{*}{ Stature $(\mathrm{cm})$} & \multicolumn{2}{|c|}{ Head Size $(\mathrm{cm})$} & \multirow{2}{*}{$\begin{array}{l}\text { Head } \\
\text { Index }\end{array}$} & \multirow{2}{*}{$\begin{array}{l}\text { Nasal } \\
\text { Index }\end{array}$} \\
\hline & & Length & Breadth & & \\
\hline Okkaliyan & 166.0 & 18.6 & 14.4 & 77.3 & 73.5 \\
\hline Bedar & 165.4 & 16.0 & 14.0 & 77.0 & 79.4 \\
\hline Dasa Banajiga & 165.3 & 18.1 & 14.0 & 77.3 & 72.8 \\
\hline Kappu & 164.5 & 18.2 & 14.2 & 78.0 & 72.9 \\
\hline Pallan & 164.3 & 18.3 & 13.9 & 75.9 & 73.2 \\
\hline Idaiyan & 164.3 & 18.3 & 13.9 & 75.9 & 73.6 \\
\hline Tota Balija & 163.9 & 18.1 & 14.1 & 78.0 & 74.1 \\
\hline Golla & 163.8 & 18.2 & 14.1 & 77.5 & 74.1 \\
\hline Sedan & 163.3 & 18.4 & 14.1 & 76.6 & 72.7 \\
\hline Kuruba & 162.7 & 18.3 & 14.1 & 76.6 & 74.9 \\
\hline Komati & 162.5 & 17.6 & 14.5 & 82.2 & 77.8 \\
\hline Vellala & 162.4 & 18.6 & 13.8 & 74.2 & 73.1 \\
\hline Panchala & 162.3 & 18.2 & 14.2 & 87.9 & 74.8 \\
\hline Chakkaliyan & 162.2 & 18.2 & 13.5 & 74.5 & 78.9 \\
\hline Boya & 160.8 & 18.2 & 14.2 & 77.9 & 74.4 \\
\hline Togata & 160.5 & 17.7 & 14.3 & 80.0 & 77.5 \\
\hline Padmasale & 159.9 & 17.8 & 14.1 & 78.7 & 73.2 \\
\hline Mean & 162.9 & 18.2 & 14.1 & 77.9 & 74.7 \\
\hline $\mathrm{CD}$ & 3.72 & 0.51 & 0.43 & 6.06 & 8.64 \\
\hline 95\% Upper confidence Limit & 162.0 & 18.03 & 13.97 & 76.44 & 73.65 \\
\hline 95\% Lower confidence Limit & 163.9 & 18.30 & 14.19 & 79.51 & 75.79 \\
\hline
\end{tabular}

viable and biologically sound. Such unification will contribute greatly for furthering 'oneness' and end in re-emergence of earlier casteless society as the existing caste system 'casts a shadow over culture' (Karthikeyan, 1999) for developing the charity, brother hood and social harmony in the pluralistic society of India to meet the challenges posed to the society by the new 


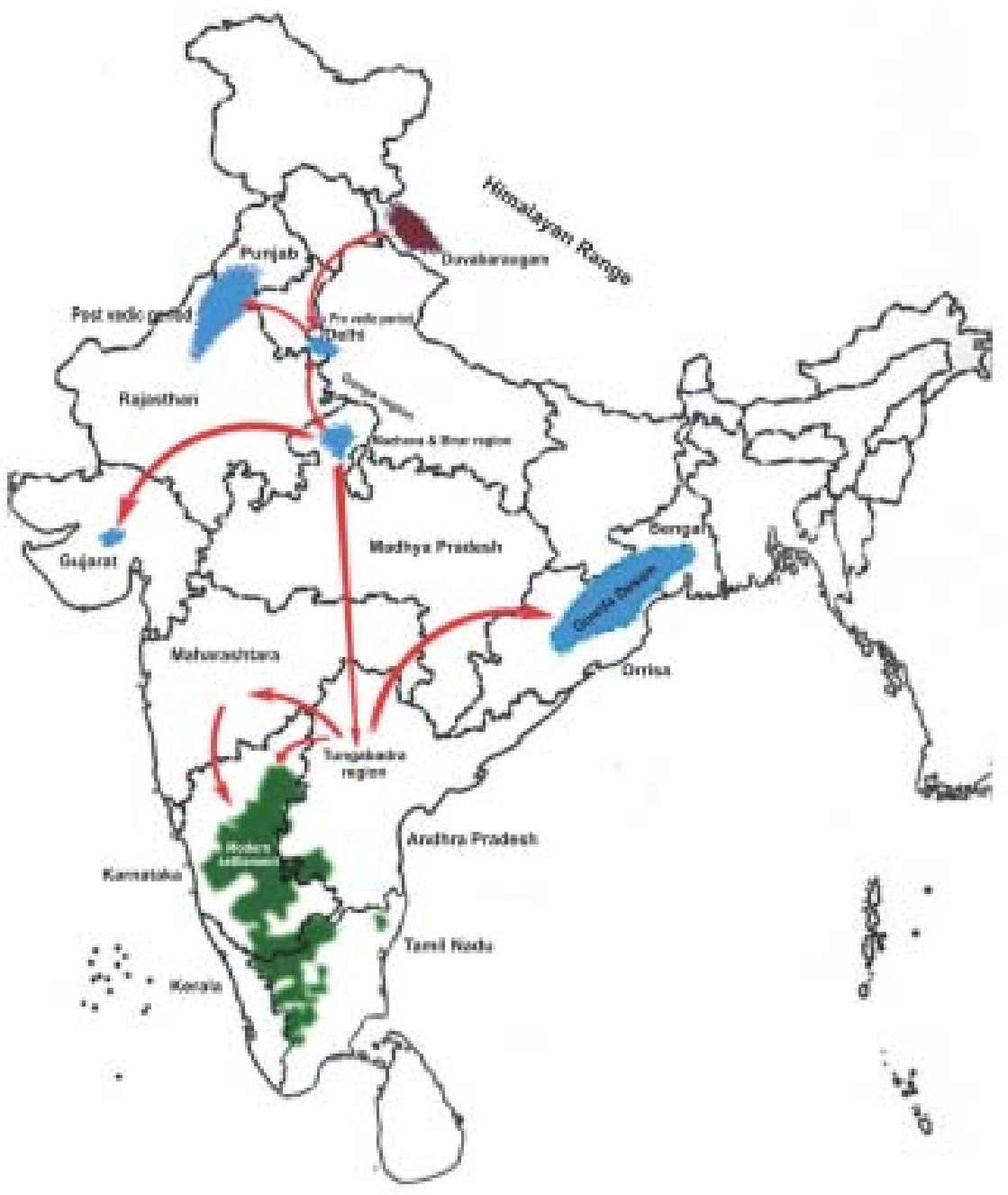

Fig. 1. The shaded area show the habitats of Okkaligar community. The arrows indicate their movements from North India during different periods of history and regimes

world order. The culture of 'oneness' will bring harmony among the different communities and the best understanding on the value of human beings which will enable equitable sharing of natural and man made resources for living.

\section{GENESIS OF KULAMS AND ARRANGING MARRIAGES}

The Kulams are an identity carried by male lineage used for fixing the descendents of a family that was originally based on the behaviour and professions of males. The modern DNA and genetic research have proved that this system carries science and confirmed that the transference of male Y-chromosome intact from father to son over several generations as evidenced in the case of U.S President Thomas Jefferson (Lander and Joseph, 1998 and Foster et al., 1998). The females do not carry the Y-chromosomes. The names of the 48 male individuals of Okkaligar who belonged to pre Vedic period (Subbaiah, 1911, Veerakyathaiah and Thimmaiah, 1994) became the names of the Kulams as given in the Table 1. The wives of these persons were worshiped as family Goddess during latter periods at their various settlements. The kulams were also named after the places of living, family 
deities, based on the ownership of land, after the names of the animals and the position that they held in the villages or group at new settlements during the post Vedic periods. The number of kulams has increased in the kunchidigar (Veerakyathaiah, 2005) as well as in other subdivisions either during the post Vedic or Imperial period for accommodating the newer environments aroused due to infiltration of other cultures, the rivalry with in the community and intermarriages held with in and out side the four major divisions resulting new cultures and also ego of dominating persons. This system is scientifically sound and perhaps first in the world for laying the foundation for the modern science of hybridization and exploitation of hybrid vigour in the human population and for averting the inbreeding depression and genetic decline in the community. This system also helped to lay the moral codes for peaceful living.

There are several socio economic and emotional factors that decide the marriages in their community. The marriages are usually done with in the settlements among blood relatives of different kulams which amounted to inbreeding and this practice should be discouraged for widening the existing narrow genetic base of the population. The marriages that are made out side the blood relation and settlements will improve their stock and also integrate the scattered population in different settlements and resolve the conflicts if any and unhealthy competition with in and outside the community.

The Status of Okkaligars and their Contributions to the Society: According to the Ethirographical Survey of Mysore, India the Okkaligars were engaged in agriculture and armory during the Krishna-devarayar period in his Kingdom (Palaniswamy, 1988). They remained mostly as illiterates working hard in the agricultural fields and content with the subsistence level of living during the Imperial period. On the other hand the upper caste was in dominating position in almost all fields of human management in the society from the Vedic to Imperial periods due to the facts that they were literates and had good command over Vedic scriptures and English language. But this situation had under gone seeping changes due to the efforts of various Missionaries, several philosophers, rationalists, philanthropists and the educational activities of Governments that improved the native talents and skills of the population of other castes. The Okkaligars by acquiring the education and skill opted for different professions besides doing their traditional agriculture and improved their social status and style of living during the post Independence period of the country. The current status of their population comprises daily wage earning illiterates, professionals, and affluent industrialists and reputed Scientists who are serving the society in different parts of the world in different capacities. The acquired knowledge and wealth be directed for meeting the social obligation of uplifting the economically weaker sections within and outside the castes and for the harmony of mankind.

They have made very impressive contributions not only in the field of production of agriculture, horticultural, floricultural products and marketing but also in the fields of environment, forestry, education, linguistics, arts, culture, health and medicine, sciences including the modern technologies, industries, trades, commerce, charity, social, justice, law and order, state administration, politics and cinematography. Their sustained efforts in these fields facilitated the improvement of the standard of living of people, which enabled the overall growth, and development of their settlements and the country to a great extent.

\section{ACKNOWLEDGEMENTS}

The author is grateful to Dr. K. Perumalsamy, Chief Librarian of Tamilnadu Agricultural University, Coimbatore for permitting him to use the Library, Mrs. D. Subhadra, Sugarcane Breeding Institute, Coimbatore for analyzing the data and to Mr. D. Suryanarayanan of Suri Associates, Coimbatore for his graphic work.

\section{NOTES}

1. Lingam naturally occurring oval stone is used as a symbol for worship of the Hindu God Shiva. It is also sculptured and worshiped.

2. Kamadhenu is Cow with the human face Mythological God is worshiped by the Hindu.

3. Aryan is an English word derived from the Sanskrit term arya, means noble and never a race. The Rigveda also uses the word 'Arya thirty six times, but never to mean a race'. The authoritative Sanskrit lexicon (c. 450 AD) defines, as 'An Arya is one who hails from a noble family, of gentle behavior and demeanor, good-natured and of righteous conduct'. The great epic Ramayana describes Rama as 'arya sarva samascaiva sadaiva priyadarsanah' that means 
'Arya, who worked for the equality of all and was dear to everyone'

4. Adi Perukku is a festival celebrated on 18th of the month of Adi (3rd or 4th of August) by most of the communities in South India when the Rivers are in spate due to the monsoon rains. Perukku means spate of the rivers. Ashada and Adi are the names of the months in Kannadam and Tamil languages respectively.

5. Nandhi is White Bull, which God Shiva rides, the sculpture of Nandhi used to be in laying posture at the entrance of every Shiva Temple is worshiped by the Hindu.

\section{REFERENCES}

Anonymous: Document No.2334 dated 9 October 1899, Office of Registrar, Coimbatore, Tamilnadu (1899).

Anonymous: Document No.226 dated 11 Sep 1914, Office of Tresur of Registrar, Hiriyur, Chital Droog (Chitradurga), Karnataka (1914a).

Anonymous: Document No.227 dated 16 Aug 1914, Office of Tresur of Registrar, Hiriyur, Chital Droog (Chitradurga), Karnataka (1914b).

Anonymous: Significance of Mayiladuthurai find- Links between Harappa and Neolithic Tamilnadu, The Hindu, 129(103): p.20 (2006)

Bamshad, M.J., Watkins, W.S., Dixon, M.E., Jorde,L.B., Rao, B.B., Naidu, J.M., Prasad, B.V., Rasanayagam,A., and Hammer. M.F.: Female gene flow stratifies Hindu castes. Nature, 395(6703): 651-652 (1998).

Bamshad, M., Kivisild, T., Scott Watkins, W., Dixon, M E., Ricker, C. E., Rao, B. B., Naidu, J. M., Ravi Prasad, B.V., Govinda Reddy, P., Rasanayagam, A., Papiha, S. S., Villems, R., Redd, A. J., Hammer, M. F., Nguyen, S. V., Carroll, M. L., Batzer, M.A., and Jorde, L. B.: Genetic evidence on the origin of Indian caste populations. Genome Res., 11: 994-1004 (2001).

Basu, A., Mukherjee, N., Roy, S., Sengupta,S., Banerjee, S., Chakraborty, S.M., Dey, B., Roy, M., Roy, B., Bhattacharya, N. P., Roychoudhury, S. and Majumder, P. P.: Ethnic India: A genomic view, with special reference to peopling and structure, Genome Research, 13: 2277-2290 (2003).

Cordaux, R., Aunger, R., Bentley, G., Nasidze, I., Sirajuddin, S. M. and Stoneking, M.: Independent origins of Indian caste and tribal paternal lineages. Current Biol., 14: 231-235 (2004).

Danniel, A.: Informations on India- Religions in India (2004). From < Pezarkar.com> (Retrived December $21,2005)$.

Deivanayagam, M. and Devakala, D: Christianity in
Hinduism, Dravidian Religion Trust, Page 107 (1997).

Gordan, Raymond Jr. (Ed.): Ethnolgue: Languages World. Fifth edition. Dallas: SIL. International Online version (2005). From < http://www.ethnologue.com/ $>$ (Retrived February 13, 2006).

Foster, E.A., Jobling, M.A., Taylor, P.G., Donnelly, P., deKnijiff, P., Mieremel, R., Zerjal, T. and TylerSmith. C.: Jefferson fathered Slave's last child. Nature, 396: 27-2814 (1988).

Hebbar, N. H.: Caste and Karma (2002), from< India Nest.com, (Retrived December 21, 2005).

Jayaraman, V.: Caste System is the biggest threat to Hinduism, History: Essays on the history of hinduism and related religions (2001). From< Hindu website, (Retrived December 21, 2005).

Karashima .N.: Tamil inscriptions point to the existence of challenge to caste. The Hindu, 129(39): p.15 (2006)

Karthikeyan.V.: Castes cast a shadow over culture. Indian Currents, Oct, 11-17, 1999 p.34 (1999).

Kivisild, T., Kaldma, K., Metspalu, M., Parik, J., Papiha, S. and Villems, R.: The place of Indian mitochondrial DNA variants in the global network of the maternal lineages and the peopling of the old world. pp. 135152, In: Genome Diversity: Applications in Human Population Genetics. S.S. Papiha et al. (Eds.). Kluwer, New York (1999b).

Lander, E.S. and Joseph, J.E.: Founding father. Nature, 396: 13-141 (1998).

Natarasan, N.: Konghu Velhala Goundarghal. Pallavi Publisher Publishers, Chennai (1999).

Palaniswamy, S.K.: Kunjidiga Jannangal Parreyha Orr Aaivu, In: Special issue on Okkaligar (Kappu) Varalaru, Vallakkavar (alias) Badavanaver Sangam, Dindugul, Tamilnadu (1988).

Subbaiah, C.: Kamukula Urbhva Puranam, (Based on the Kannada literatures found on copper plates and palm leaves found in Archives). Madras Diamond Printing House, Madras (1911)

Thurston, E. and Rangachari, K.: Castes and Tribes of South India. Government Press, Madras (1909).

Veerakyathaiah, V.D. and Thimmaiah, G.: Kunchidiga Jananga, Ithihasa Hagu Sampradayagal, Akila Kunchitigara Mahamandala, Bangalore, Karnataka (1994).

Veerakyathaiah: Origin of Kunjitigas, Their Chieftains, Gothras, Family Deities and Brother-hood, Akila Kunchitigara Mahamandala, Bangalore, Karnataka, (In print). (2005)

Wooding, S. Ostler, C., Prasad, B.V., Watkins, W.S., Sung, S., Bamshad, M. and Jorde, L.B.: Migration in the Hindu castes: Inferences from mitochondrial, autosomal and Y-chromosomal data. Hum. Genet., 115(3): 221-229 (2004). 